\title{
The effect of giving boiled water of sirsake on the reduction of uric acid
}

\author{
Riyo Fajar Iman', Ikhsan Mujahid² \\ ${ }^{1,2}$ Nursing Study Program, Muhammadiyah University of Purwokerto
}

\begin{abstract}
ARTICLE INFO
\section{ABSTRACT}

Article history:

Received: August 9, 2020

Revised: August 20, 2020

Accepted: August 30, 2020

Keywords:

soursop leaf stew, uric acid, decreased uric acid levels

Uric acid is a disease characterized by pain due to deposits of monosodium urate crystals that accumulate in the joints as a result of high levels of uric acid in the blood. Consuming soursop leaf decoction (Annona muricata Linn) is one type of non-pharmacological therapy that functions as an analgesic that can reduce uric acid levels and relieve pain. This study was to analyze the effect of giving soursop leaf boiled water on reducing uric acid levels in gout sufferers. This study used a quantitative method with a quasy experimental design control group pretest posttest. The sampling technique was random sampling. The number of samples was 34 people with uric acid levels, where 17 people were treated with soursop leaf water and 17 were a control group around the working area of the Pulosari Community Health Center. The data collection instrument used observation, data analysis used statistical test, normality test, paired samples test, homogeneity test and independent test. The results of paired t-test on soursop leaf boiled water showed changes in blood uric acid levels with a p-value of 0.000 . The results of the paired t-test in the control group found no significant change in blood uric acid levels before and after with a p-value of 0.016 . The results of the Independent $\mathrm{t}$-test found that there were significant differences between the provision of boiled water for soursop leaves and the control group. In conclusion this shows that consuming soursop leaf boiled water can reduce uric acid levels in the blood and there are changes in uric acid levels before and after being given soursop leaf boiled water.
\end{abstract}

This work is licensed under a Creative Commons Attribution 4.0 International License.

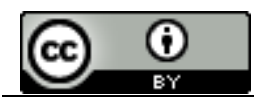

\section{Corresponding Author:}

Riyo Fajar Iman,

Student of nursing Program Faculty of Health Sciences

University of Muhammadiyah Purwokerto

Riofajariman280497@gmail.com

\section{INTRODUCTION}

The increase in life expectancy and nutritional status for the community in the last decade has led to a transition to lifestyle habits, including diet. This has an impact on the change from an infectious disease to a non-communicable disease. Changes in disease patterns are related to diet, from a traditional diet that contains lots of fiber and vegetables to a diet with a high protein, fat and salt composition. A diet that contains lots of purines, if the metabolic process is disturbed, the uric acid levels in the blood will increase and cause a buildup of uric acid crystals [1]. Uric acid is a substance that results from purine metabolism in the body. This uric acid substance will usually be excreted by the kidneys through urine under normal conditions (Herman, 2014). This situation will trigger an inflammatory response that causes pain, this is what is known as gout (Mayer, 2011). High uric acid levels will cause an increase in uric acid crystals that are shaped like needles, especially in joints which will cause pain.

Report date states that the percentage of those suffering from joint disease in Indonesia is $24.7 \%$. In men $13.4 \%$ and women $11.3 \%$. These data indicate that men are dominant in experiencing joint pain than women. The prevalence of uric acid in Central Java reached 165,375 patients, this number consists of 48,055 people ( $45-59$ years old), 42,787 people ( $\geq 60$ years), more male patients than female patients with the peak 
proportion of age. 50 years (BPS, 2010). An epidemiological survey conducted in Central Java in cooperation with WHO shows that the percentage of suffering from joint disease in Indonesia is $24.7 \%, 13.4 \%$ in men and $11.3 \%$ in women. These data show that men are more dominant in experiencing joint pain [2].

Handling taken to reduce uric acid can be done pharmacologically and non-pharmacologically. Pharmacologists use NSAIDs, colchicine and corticosteroid drugs and therapy for chronic gout which functions to reduce uric acid production [3], while non-pharmacological treatments can utilize surrounding plants such as bay leaves, cherry fruit, and soursop. Because of a series of side effects, there must be alternatives to drugs that are more effective in treating gout or hyperuricemia. One of them is using existing drugs in the surrounding environment, namely plants, by conducting research on herbal medicines that have an effect on reducing uric acid levels and have minimal side effects [4]. In Indonesia, there are various plants that have been studied contain many of the same substances as allopurinol and are useful in the treatment of gout, one of which is soursop leaves [5]. Soursop is a plant that is easily available and has benefits from roots to fruit. In soursop leaves, there are acetogenin content which is antioxidant, and also contains flafonoid compounds [6].

The results of a preliminary study of data from the Pulosari Health Center show that the number of atritical gout sufferers aged 45-50 years is 21 people, aged 55-59 are 8 people, aged 60-69 years is 10 people, and aged $>70$ years is 3 people. Based on the above background, the researcher wanted to examine the effect of giving soursop. Boiled water on reducing uric acid levels. The purpose of this study was to determine the effect of the characteristics of respondents with gout and the effect of boiled water from soursop leaves on reducing uric acid levels in uric acid sufferers, to identify the characteristics of respondents based on gender, age, education, occupation, family history, and diet, determine levels uric acid before and after being given soursop leaf boiled water and knowing the effect of giving soursop leaf boiled water on decreasing uric acid levels.

\section{RESEARCH METHOD}

This study used a quantitative method with a quasy experimental design with a pretest and posttest control group approach. Namely the research design by comparing before and after so that the results can be known more accurately [7]. This research was conducted on 12-20 February 2020. The population of this study were 57 people with uric acid in the Pulosari district health center. Samples in this study were 30 people, 15 people in the intervention group and 15 people in the control group. To avoid Drop Out in the study, it is necessary to increase the number of samples so that the sample size is still fulfilled by $10 \%(\mathrm{f}=0.1)$ of the respondents to 17 people per group. So the number of samples of 17 people became the treatment / intervention group, 17 people became the comparison group, so the total sample was 34 people.

In the intervention group treated with $200 \mathrm{ml}$ of soursop leaf boiled water and in the control group only the comparison group. The number of samples taken in this study were 34 respondents who met the research requirements. The research site is in the penakir village of Pulosari sub-district. The instruments in this study used observation and measurement sheets using the before and after nesco multi check tool. Sampling in this study is to use a non-probability sampling technique, purposive sampling type, which is a sampling technique by selecting samples from among the population according to what the researcher wants (objectives / problems in the study), so that the sample can represent the characteristics of the population that have been known previously.

\section{RESULTS AND DISCUSSIONS}

\subsection{Research results}

Table 1. The distribution of the characteristics of the respondents in the area around the Puskesmas Pulosari Characteristics

\begin{tabular}{lcccc}
\hline \multirow{2}{*}{ Characteristics } & \multicolumn{3}{c}{ Group } \\
\cline { 2 - 5 } & \multicolumn{2}{c}{ Eksperiment (n=17) } & \multicolumn{2}{c}{ Control (n=17) } \\
\cline { 2 - 5 } Gender & Frequency & Percentage & Frequency & Percentage \\
$\quad$ Male & 8 & $47,1 \%$ & 6 & $35,3 \%$ \\
$\quad$ Women & 9 & $57,9 \%$ & 11 & $64,7 \%$ \\
Age & & & & \\
$\quad$ 34-44 Years & 5 & $29,4 \%$ & 6 & $11,8 \%$ \\
45-59 Years & 6 & $35,3 \%$ & 11 & $64,7 \%$ \\
60-74 Years & 5 & $29,4 \%$ & 4 & $23,5 \%$ \\
75-90 years & 1 & $5,9 \%$ & - & - \\
Education & 5 & & & \\
$\quad$ Didn't finish school & 9 & $29,4 \%$ & 5 & $29,4 \%$ \\
$\quad$ Prelemetary & 3 & $52,9 \%$ & 11 & $64,7 \%$ \\
$\quad$ Junior High school & & $17,6 \%$ & 1 & $5,9 \%$
\end{tabular}




\section{Profession}

Farmers / laborers

Housewife

Traders

Entrepreneur

Family History uricacid

Ever

Never

Dietary habit

Not a purine diet

Purine diet

$\begin{array}{cccc}12 & 70,6 \% & 8 & 47,1 \% \\ 4 & 23,5 \% & 8 & 47,1 \% \\ 1 & 5,9 \% & - & - \\ - & - & 1 & 5,8 \% \\ 17 & 100 \% & 17 & 100 \% \\ - & - & - & - \\ & - & 14 & 82,4 \% \\ - & 100 \% & 3 & 17,6 \% \\ 17 & & & \end{array}$

Table 2. The results of statistical analysis of uric acid levels after being given boiled water for soursop leaves, the intervention group and control group in the Pulosari Health Center work area

\begin{tabular}{lcccccccc}
\hline \multirow{2}{*}{ Measurement } & \multicolumn{4}{c}{ Group eksperiment } & \multicolumn{4}{c}{ Group control } \\
\cline { 2 - 9 } & Mean & SD & t & p & Mean & SD & t & p \\
\hline Pretest & 8,624 & 1,3984 & 9,13 & 0,000 & 7,853 & 0,5636 & 2,701 & 0,016 \\
Posttest & 5,859 & 0,9028 & & & 7,547 & 0,6186 & &
\end{tabular}

Table 3. Differences in uric acid levels after being given boiled water for soursop leaves between the intervention group and the control group in the working area of the Pulosari Health Center

\begin{tabular}{cccccc}
\hline Measurement & n & Mean & SD & t & p-value \\
\hline Eksperiment- & 17 & 7,547 & 0,9028 & $-6,360$ & 0,000 \\
Control & 17 & 0,255 & 0,6186 & &
\end{tabular}

\subsection{Discussion}

Of the 34 respondents studied, it was found that the percentage of respondents who experienced arthritis gout pain was in the intervention group giving soursop leaf boiled water that was dominated by 9 women $(57.9 \%)$ while the number of respondents in the control group was dominated by 11 women $(64.7 \%)$. This is supported by Mulyadin's research in the work area of Puskesmas Pineleng, with the results of 34 respondents being researched that respondents who experienced gout were aged 60-74 years. This is in line with the research conducted with the title of the relationship of social support to the degree of pain in acute phase gout sufferers, which states that the age of many patients is 51-74 years [8]. According to the theory put forward by Ode, age can be a risk factor for gout because when a person gets older there will be a change or decrease in the process of metabilism in the body and uric acid is a disease that is caused by metabolic disorders in the body [9].

The majority of uric acid sufferers were aged between 45-59 years of age with gout. Naturally, men aged over 30 years are more susceptible to gout. This is because uric acid levels in men are quite high, meanwhile, acid levels in women are generally low and only increase after menopause. Female respondents who experienced an increase in uric acid levels were on average over 50 years of age and were already at the age [10]. Age is associated with increased uric acid levels, when the age $>50$ years will experience changes both physically, mentally and psychologically. One physical change is a decrease in kidney function which results in an increase in uric acid levels due to the kidneys being unable to excrete purines properly resulting in deposition of purines.

Elementary school graduates dominate the education level of respondents in the intervention group and in the control group the majority of respondents have primary school education. Educational factors affect a person's health level, respondents with high education, so the attention to food is better than those with low levels of education. The level of education has an effect on the utilization of health service facilities, the higher the intensity of the use of health service facilities the higher. Those with high education generally behave differently from those with low education, where most of the respondents with low education have high uric acid levels.

All respondents have a history of gout and the respondents' occupation is dominated by farmers / laborers, both in the intervention and control groups. Some opinions suggest that strenuous activity can aggravate gout, which is characterized by an increase in uric acid levels in the blood. Exercise or physical movement will cause an increase in lactic acid levels. Increasing the level of lactic acid in the blood, the uric 
acid secretion decreases so that the uric acid content in the body increases. This is reinforced by the opinion of Mayers which states that lactic acid is formed from the glucuric process that occurs in muscles. The increase in lactic acid in the blood will cause a decrease in uric acid excretion by the kidneys. The increase in lactic acid levels cannot be measured with certainty because we cannot determine when the muscles of the body contract anaerobically. The majority of respondents do strenuous activities but the frequency is not certain, some do routine exercise but are not done every day.

In this study, a normality test was carried out in the intervention group, which obtained a p-value of 0.200 where a value of $>0.05$ could be said that the data were normally distributed. The results showed that there was a decrease in uric acid levels in uric acid sufferers before and after, this can be seen through the paired samples test obtained $\mathrm{p}$-value $=0.000(\mathrm{p}$-value $<0.05)$ in the intervention group which means that it shows a significant effect on consuming. Boiled water of soursop leaves to reduce pain in people with gout arthritis. By consuming it for 7 days in a row. In the control group p-value $=0.016$ (p-value $>0.05$ ), it can be concluded that there is no significant effect of reducing acid levels in the control group. The maximum value of $11.2 \mathrm{mg} / \mathrm{dl}$ becomes $7.6 \mathrm{mg} / \mathrm{dl}$, the minimum value of $7.0 \mathrm{mg} / \mathrm{dl}$ becomes $4.2 \mathrm{mg} / \mathrm{dl}$, with the median value before therapy is $7,800 \mathrm{mg} / \mathrm{dl}$ to $5,800 \mathrm{mg} / \mathrm{dl}$.

The results of this study are in accordance with the theory put forward where consuming soursop leaf decoction can reduce pain in patients with arthritis gout without any side effects because it does not contain chemicals with properties and benefits that have been recognized by researchers. Changes in uric acid levels in the blood in boiled water from soursop leaves are influenced by the content of acetogenin and flavonoid compounds. Acetogenin itself can act as an antioxidant which can reduce the formation of uric acid through inhibition of the xanthine oxidase enzyme. While the content of flavonoid compounds itself has a mechanism similar to that of allopurinol, namely by inhibiting the xanthine oxsidase enzyme which plays a role in the process of converting hypoxanthine to xanthine and ultimately into uric acid. The effect of consuming soursop leaf decoction on pain reduction in patients with arthritis gout is due to the content of tannins, resinous and crystallizable in soursop leaves and the respondents did not show any side effects because the content in soursop leaves was not harmful in the body.

Based on the results of the independent t-test with the help of spss 16, the difference between the results of the test showed that there was a difference in effectiveness between the blood uric acid levels given boiled soursop leaf therapy and the control group, so it could be said that H0 was rejected and H1 was accepted, which means that there was a difference between the intervention groups. And the control group on changes in blood uric acid levels in uric acid patients in the Pulosari Health Center working area. Based on the analysis, it was found that the mean reduction in blood uric acid levels with the therapy of soursop leaf boiled water and the control group showed that the administration of soursop leaf water boiled therapy was more effective in reducing uric acid levels.

The decrease in uric acid levels before and after giving the soursop leaf stew is caused by the active substances in soursop leaves, namely alkaloids and flavonoids which can reduce uric acid levels. According to Handayani soursop leaf boiled water contains antioxidants, namely flavonoids [11]. Flavonoids are diuretic compounds to increase the amount of urine production so that purines can be excreted through urine, Trubus. Flavonoids can increase urination and electrolyte output through their influence on the glomerular filtration rate (GFR) in the Bowman's capsule. Flavonoids function like potassium, which absorbs electrolyte ions such as sodium in the extracellular blood to go extracellularly to enter the kidney tubules [12]. The high glomerular Filtration Rate (GFR) due to the flavonoid activity causes the kidneys (in the proximal tubule as much as $65 \%$ and ansa henle as much as $25 \%$ ) to be able to remove waste products from the body quickly, besides that it can cause all body fluids to be filtered and processed by kidneys (in tubular cholingetes) all the time every day and are able to adjust the volume and composition of body fluids appropriately and precisely [13]. Thus that the provision of soursop leaf decoction has an effect in reducing uric acid levels in the blood.

\section{CONCLUSION}

Provision of boiled water for soursop leaves to respondents suffering from arthritis gout also experienced a decrease in the results of gout examination. From all respondents, before being given boiled water for soursop leaves, uric acid was examined with uric acid results above the normal limit, which is more than $6.0 \mathrm{mg} / \mathrm{dl}$ for women and $7.0 \mathrm{mg} / \mathrm{dl}$ for men. After being given boiled water for soursop leaves with a dose of 1 cup $(200 \mathrm{cc})$ of boiled water, given $2 \mathrm{x} /$ day for 7 days, the respondents experienced a decrease in the results of uric acid examination, although not all respondents experienced a decrease in uric acid within normal limits.

\section{Acknowledgements}

Thank you to the people of Penakir village who have participated in this research and are willing to become respondents, and to the village head who has allowed and supported this research. 


\section{REFERENCES}

[1] A. Zakiyah, Pain: Concepts and Management in Evidence-Based Nursing Practice, Jakarta: Salemba Medika, 2015.

[2] Riskesdas, "Basic Health Research on Joint Diseases," 2013. [Online]. Available: www.litbang.depkes.go.id.

[3] Z. Helmi, Musculoskeletal Disorders Textbook, Jakarta: Salemba Medika, 2012.

[4] Ardhilla, Diet Guide, Jakarta: PT Gramedia Pustaka Utama, 2013.

[5] Fanany, Exorbitant Efficacy of Soursop Leaves, Mangosteen Skin, Noni Crushed Various Chronic Diseases, Yogyakarta: Araska, 2013.

[6] B. Rachmat, "The Effect of Soursop (Annona Muricata Linn) Leaf Infusion on Decreasing Blood Uric Acid Levels in Hyperuricemia Model Mice,” Bandung Islamic University, Bandung, 2014.

[7] Nursalam, Nursing Research Methodology: A Practical Approach, 3 penyunt., Jakarta: Salemba Medika, 2014.

[8] Widi, "The Relationship between Social Support and the Degree of Pain in Patients with Acute Phase Arthritis Gout," Public Medicine News, vol. 27, no. 1, 2011.

[9] S. Ode, Basic Concepts of Nursing., Yogyakarta: Nuha Medika, 2012.

[10] Agromedia, Healthy Solutions to Overcome Uric Acid and Rheumatism, Jakarta: PT Agromedia Pustaka, 2009.

[11] Handayani, Hana, F. H. Sriherfyna dan Yunita, "Antioxidant Extraxtion of Soursop Leaf with Ultrasonic Bath (Study of Material: Solvent Ratio and Extraction Time," Journal of Food and Agroindustry, vol. 4, no. 1, pp. 262-272, 2015.

[12] I. P. Suiroka, Degenerative Diseases, Yogyakarta: Nuha Medika, 2012.

[13] B. A. Septian dan T. D. Widyaningsih, "The Role of Black Jelly Grass Drinks (Mesona palustris BI.) For High Blood Pressure Reduction,” Journal of Food and Agroindustry, vol. 2, no. 3, pp. 198 - 202, 2014. 